\title{
DESIGNING STRUCTURED DISCUSSION FORUM FOR ADULT LEARNERS THROUGH E-COLLABORATIVE ENVIRONMENT
}

\author{
Mohd Shahril Nizam bin Shaharom ${ }^{{ }^{*}}$, Umi Kalsum Mohd Salleh ${ }^{2}$, Simin Ghavifekr $^{3}$, \\ and Muhammad Aiman Abdul Halim ${ }^{4}$ \\ ${ }^{1}$ Dr., University of Malaya, Malaysia, nizamsaril@um.edu.my \\ ${ }^{2}$ Dr., University of Malaya, Malaysia, umi_salleh@um.edu.my \\ ${ }^{3}$ Dr., University of Malaya, Malaysia, drsimin@um.edu.my \\ ${ }^{3}$ Mr., University of Malaya, Malaysia, uitm.aiman@gmail.com \\ ${ }^{*}$ Corresponding author
}

\begin{abstract}
E-collaborative environment is one of the key learning medium based on the potential functions provided in support of the learning process, specifically for the part-time adult learners. Therefore, designing for the best use of structured discussion interactive forum is the key to maximize the learning process with more flexibility. The main purpose of this paper was to develop and evaluate the diskusiMAYA platform, as an interactive forum for adult learners outside of the formal classroom. Using ADIIE Model as the framework for this study, several phases were involved in process of designing the diskusiMAYA platform including analysis phase, design phase, integration phase, implementation phase and evaluation phase. Through the diskusiMAYA platform, the log report for detailed information through field research that can record students' interaction and learning outcomes were used. Results show that there are several categories of discussions can be considered as the result of the interaction in e-collaborative learning environment through contribution of knowledge in the diskusiMAYA platform including; i) academic, ii) non-academic, iii) in the group, and iv) question and answer. All these discussion types were considered in designing the in diskusiMAYA platform as an effective tool to support the participation of adult learners. In addition, i) the students' participation through a collaborative process and collaborative stage in e-collaborative environment; ii) the use of ecollaborative environment by students and iii) the relationship between the level of participation at the level of student activity also will be discussed in this paper.
\end{abstract}

Keywords: e- collaborative environment, e-learning, interactive forum, Adult Learning, diskusiMAYA, ADIIE Model.

\section{INTRODUCTION}

Individual development through e-learning from formal to informal education could be achieved through participation in e-learning community. The outcome is not only limited to formal education and non-formal education, but also informal education which could be acquired holistically as an extension of the formal and 
non-formal education (Dib, 1988). According to Wang and Kang (2006), through formal elements and nonformal education will always involve the social presence. It is one of the three domains for online engagement should be understood that in addition to the presence of cognitive and emotive.

Learning will occur in e-learning community when the community is able to contribute in skills and proficiency development to meet a course requirement, workplace needs and enhance personal and social life experience through information sharing among community members. Communication and interaction among them is motivated by mutual benefits, commitment, intellectual, demographic similarities, hobbies, experiences or sharing of daily activities. This enables e-learning environment to shape a tool that enables two-way input and output processes in learning among the communities.

E-learning is a unique form of education as it saves cost and time. Today the use of e-learning is needed to support activities which are able to provide opportunities for participation among students. It is able to encourage individual to further his/her studies through educational programmes provided. Effective teaching methods and approaches could motivate individual to learn and share experiences outside of the formal learning session. Not all knowledge-based experiences could be shared formally or via exercise because sharing of such knowledge requires continuous maturity in creating and understanding the meaning of knowledge sharing to achieve an established objective (Lieb, 1991; Zaidatun et al., 2008).

This research will present information on formal, non-formal and informal learning combined together in the context of learner participation and the use of collaborative learning through an e-learning environment using heutagogy approach. This article summarizes by suggesting several considerations to improve and support innovative development through e-learning and formal learning based on adult learners undergoing part-time university course.

\section{STATEMENT OF THE PROBLEM}

Interaction and collaborative process among learners for knowledge sharing is always needed especially in supporting learning process via web application (Huhns \& Singh, 2005). This opportunity for continuous learning is able to encourage learners to further their studies and it does not only bring advantage in knowledge acquirement process, but also in ablity to socialize, interact, discuss and exchange opinions on an information even though they are physically separated in informal learning environment outside of classroom (Kurtus, 2005; Woodall, 2010). Situations in long-distance education in this age of technology require the use of ICT as a facilitating medium (AeU, 2010). However, for a web-based learning to be successful, learners should first strive to acquire as much skills as possible in using computer (Janarthini, 2007). The existence of such experience will ease the learner in furthering his/her studies with high motivation and self-confidence (Knowles, 1975; Lieb, 1991; Fidishun, 2000; Corley, 2008; Zaidatun et al., 2008).

Besides abilities in using technology tools as a catalyst for learning, the adult learning principles and strategies should also be taken into consideration. This is because such basic principles outline the differences between adult and children learning (Corley, 2008). The main difference between young adult and adult learners taking their degree is the time constraint, in which it becomes the main problem for adult learners taking part-time university course (Shaw \& Giacquinta, 2000). This happen because time allocation for part-time students is divided to other matters which affect their daily lives (NCES, 2007).

Through heutagogy approach, flexibility in learning process is crucial where educator provide the sources but the learners design the real course outcome (Hase \& Kenyon, 2001). Heutagogy is a self-learning approach which is based on andragogy practice and principles (Blaschke, 2012). In heutagogy approach, learners will examine their own learning process, reach to the process and question the validity of what they had learned. All these processes are based on the belief that educators should design the learning process to be more proactive instead of reactive (Eberle, 2009). The main role of educator in this process is to show learners that they are given the authority and that educator will only provide the resources only when asked or in necessary situation (Eberle, 2009). This allows learners to question and encourage inquisitiveness among them.

\section{RESEARCH PURPOSE}

The purpose of this research is to observe the knowledge construction opportunities that occur in e-learning environment through the use of e-collaborative design and heutagogy approach using the forum as one of the activities in e-learning. 


\subsection{Research Objectives}

1. To investigate how heutagogy approach could influence learners' social attendance in e-learning environment.

2. To investigate types of learning interaction which are able to construct knowledge in e-learning environment.

\section{RESEARCH METHODOLOGY}

This study was conducted using field research design, which focuses on the use of diskusiMAYA platform developed as an e-learning environment. The basic structure of these platforms use MOODLE framework, but researchers have added several technical functions which can facilitate in this study. Based on existing requirements and selected methodology, the design process of diskusiMAYA platform was done systematically and with focus on achieving the research objectives by dividing the design description into two main components (i.e. technical design and teaching design) as shown in Figure 1.

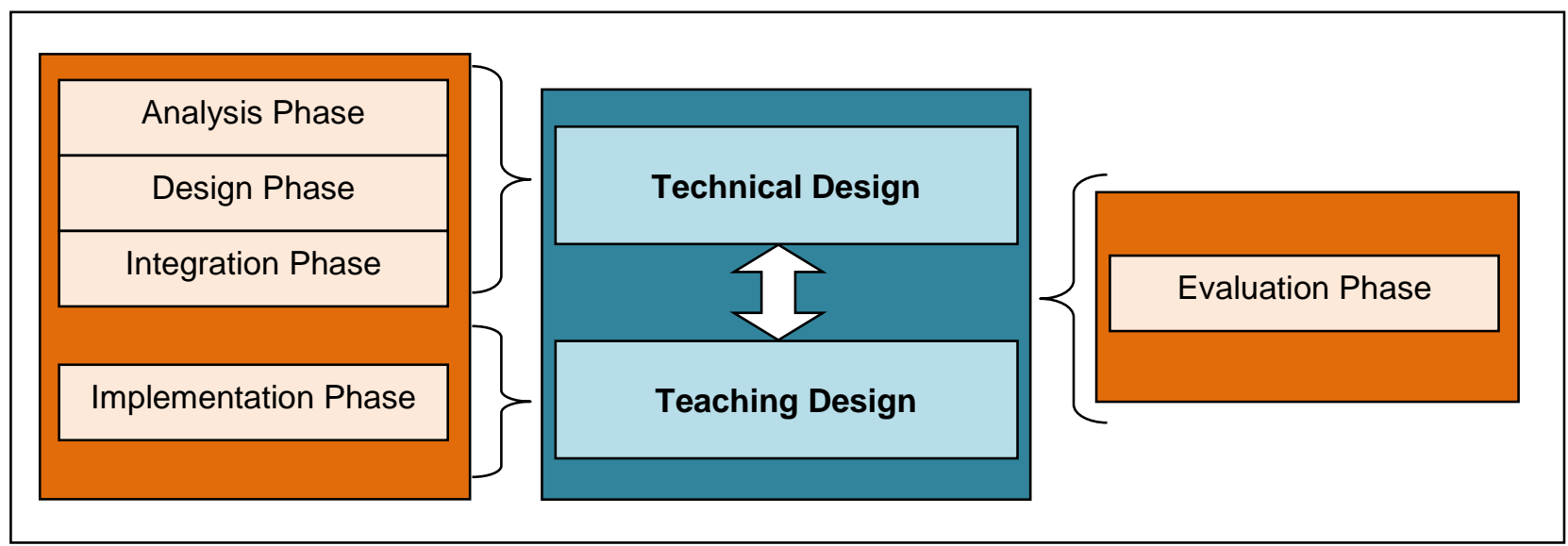

Figure 1. Use of ADIIE for Technical Function Integration Process in diskusiMAYA Platform

Users that were selected as respondents for this research were adult students which credentials and levels are established by Malaysian Qualifications Framework (MQF), namely Bachelor's Degree in level 6. The respondents are from second year and above from institutions with part-time long distance programme (offshore programme: part-time programme on weekends), regardless of the area of studies throughout the research semester (either from humanities, science or technical). Such respondent scope was selected as they have basic exposure on the use of Internet and experience in using e-learning in their previous courses. This research was conducted in two separate semesters, which is in semester 2, 2009/2010 session (research semester 1) and semester 1, 2010/2011 session (research semester 2). Figure 2 shows the setting in the implementation phase. 


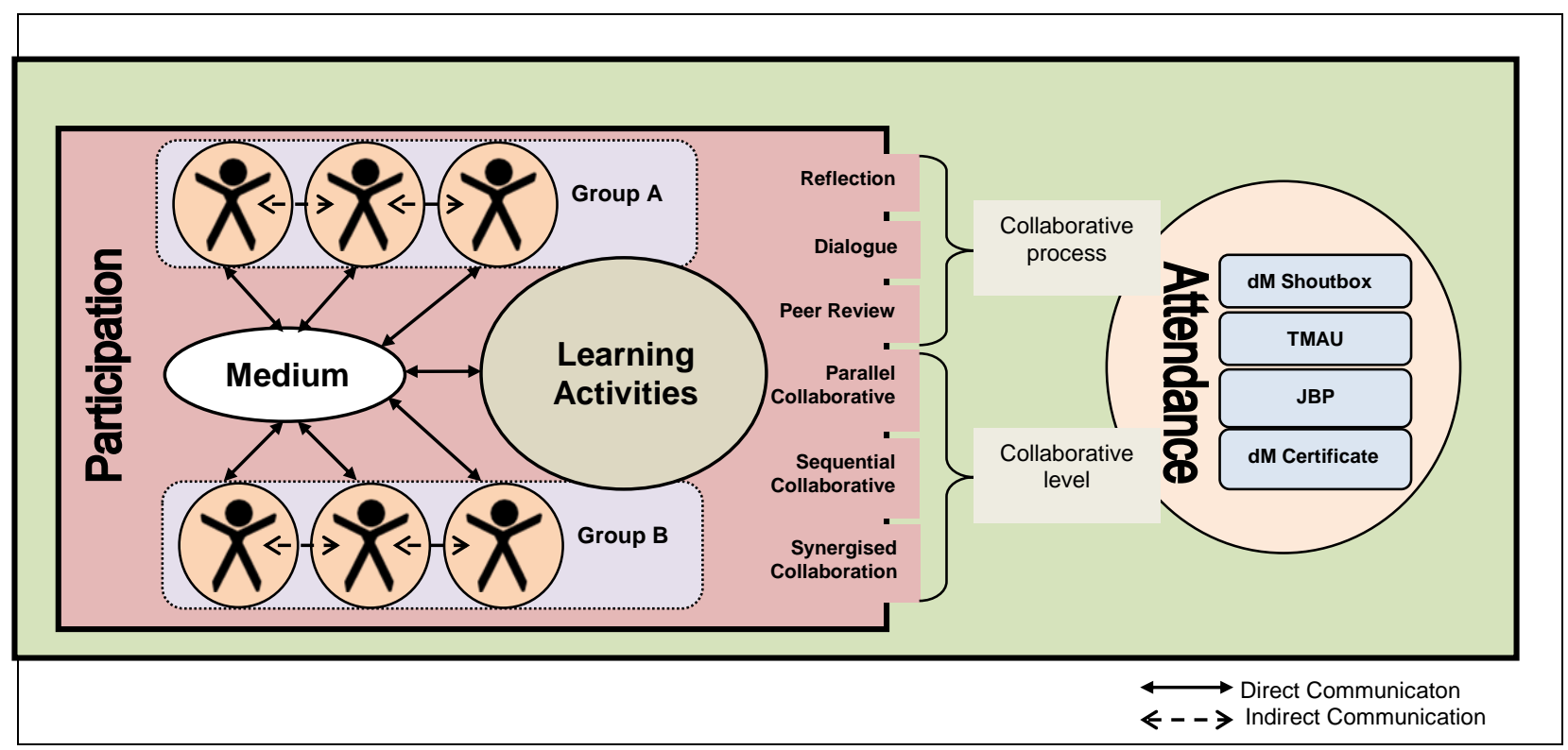

Figure 2. During The Implementation Phase.

Researchers are able to conduct continuous observation since findings for this research are generated by meta-data in e-learning environment which recorded learner interactions. Yan et al. (2003) and Conole (2008) stated that an e-learning is a field. Meanwhile, according to Bailey (2006), a field study is a systematic research especially involving interaction and observation conducted for a long term in daily life.

This research had first designed forum activities by considering every domain from Wang and Kang model (2006) into every course aspect and considering respondent background with such characteristics: i) adults and taking part-time course; and ii) majority of the respondent are not competent in using the Internet. Figure 3 illustrates how these finding reports are structured via the use of Salmons collaborative taxonomy (2011) and modification of online participation domain (Wang and Kang, 2006).

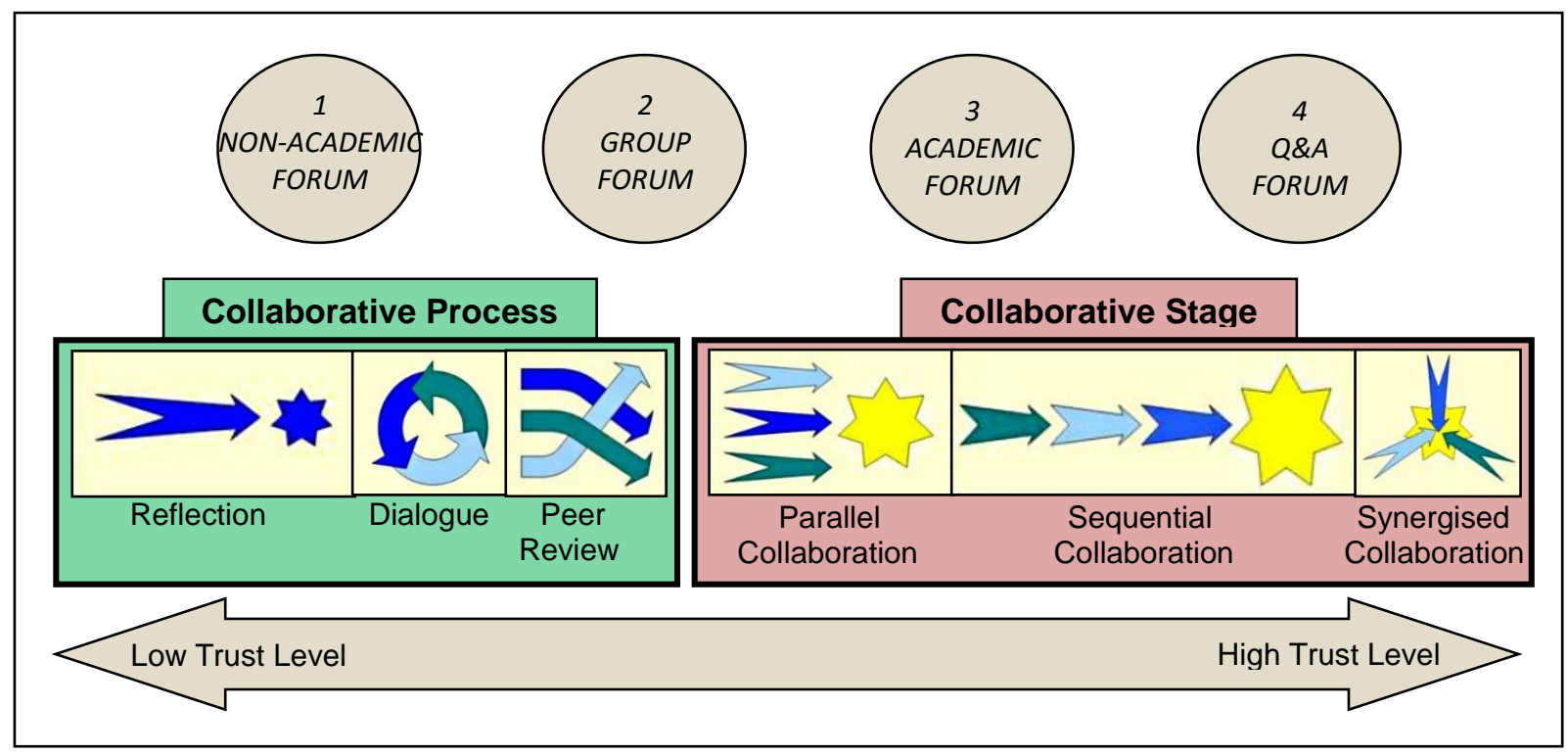

Figure 3. Interaction Forum Design in diskusiMAYA Platform.

According to $\mathrm{Li}$, Dong and Huang (2011), in a study looking at the importance of structuring e-learning through collaborative support the use of online applications, they have found that the competency of collaborative and communication activities carefully planned with the community involvement, is the most important part and suitable with the current generation of students. Focus was given on the findings from collaborative learning stages by respondents in diskusiMAYA platform, which was categorized into four forums which are modified activities from the original online participation domain (Wang and Kang, 2006). It 
was refined in Table 1 on types of interaction provided through the use of the forums in diskusiMAYA platform.

Table 1.

Types of Interaction through Gradual Use of Forums in diskusiMAYA Platform.

\begin{tabular}{|l|c|c|}
\hline \multirow{2}{*}{ Type of Interaction } & \multicolumn{2}{|c|}{ Requirement } \\
\cline { 2 - 3 } & With Requirement & Without Requirement \\
\hline Academic Related & $\sqrt{ }(6)$ & $\sqrt{ }(2)$ \\
\hline Non-academic Related & $X(3)$ & $\sqrt{ }(1)$ \\
\hline Group Discussion & & $\sqrt{ }(4)$ \\
\hline
\end{tabular}

Notes:

i) $\sqrt{ }=$ Interaction chosen by the researchers after discussion with the course lecturer and consideration on respondent's background.

ii) $\mathrm{X}=$ Interaction not chose by the researchers due to direct relation with course LO and agreement with research organization authorities.

iii) Numbers in brackets are the stages of interaction through forum which gradually started. Number 1 was the earliest forum opened and number 6 was the last forum opened.

Primary objective of a field study is to understand daily life from perspective of those within environment or social group which could be interesting for the researcher (Bailey, 2006). Field study could also be classified as a continuous research due to long period of data collection, which could take from few months to years (Bailey, 2006; Conole, 2008). Figure 4 explains the conceptual framework of this study. The description for type of activities is as follows:

\section{i) Non-academic Interaction}

The first interaction activity had started from early semester until the second week in preparation for the next activity. It provides opportunities for students with fewer competencies in e-learning usage to practice and share with the use of one medium. The existence of non-academic activities and academic oriented learning systems can enhance interaction and knowledge of students (Wang dan Kang, 2006; Li, Dong, dan Huang, 2011; Du et al., 2013). These learning activities can indirectly promote academic activities through nonoriented academic activities.

\section{ii) Academic Interaction}

After the experience of using technology medium in non-academic forum, academic interaction was introduced between the second and third week to promote the next learner interaction. This stage of interaction is still not critical as it allows learners to share knowledge gained from the course without any specific requirement.

\section{iii) Group Interaction}

Simultaneously, after their experience with two interaction design, group interaction was introduced to enable learners to interact only with their group members without interference from other group. It was started as soon as learners are divided into groups as early as the first week. They are able to discuss about their tasks in private in this section.

\section{iv) Q\&A Interaction}

Q\&A interaction is a room for learners to evaluate group tasks done by their peers. It was opened from 1 to 2 weeks starting from the last class after presentation session was completed. All learners have equal opportunity to ask, comment and constructive suggestion as well as providing attachment of articles, documents or other references as sources for their comments.

Every guideline must be aligned with the learning activities. This is because all activities are the product of planning in the course LO document. Every guideline was prepared beforehand so as the learners are aware of the limits for their participation according to their current programmes. 


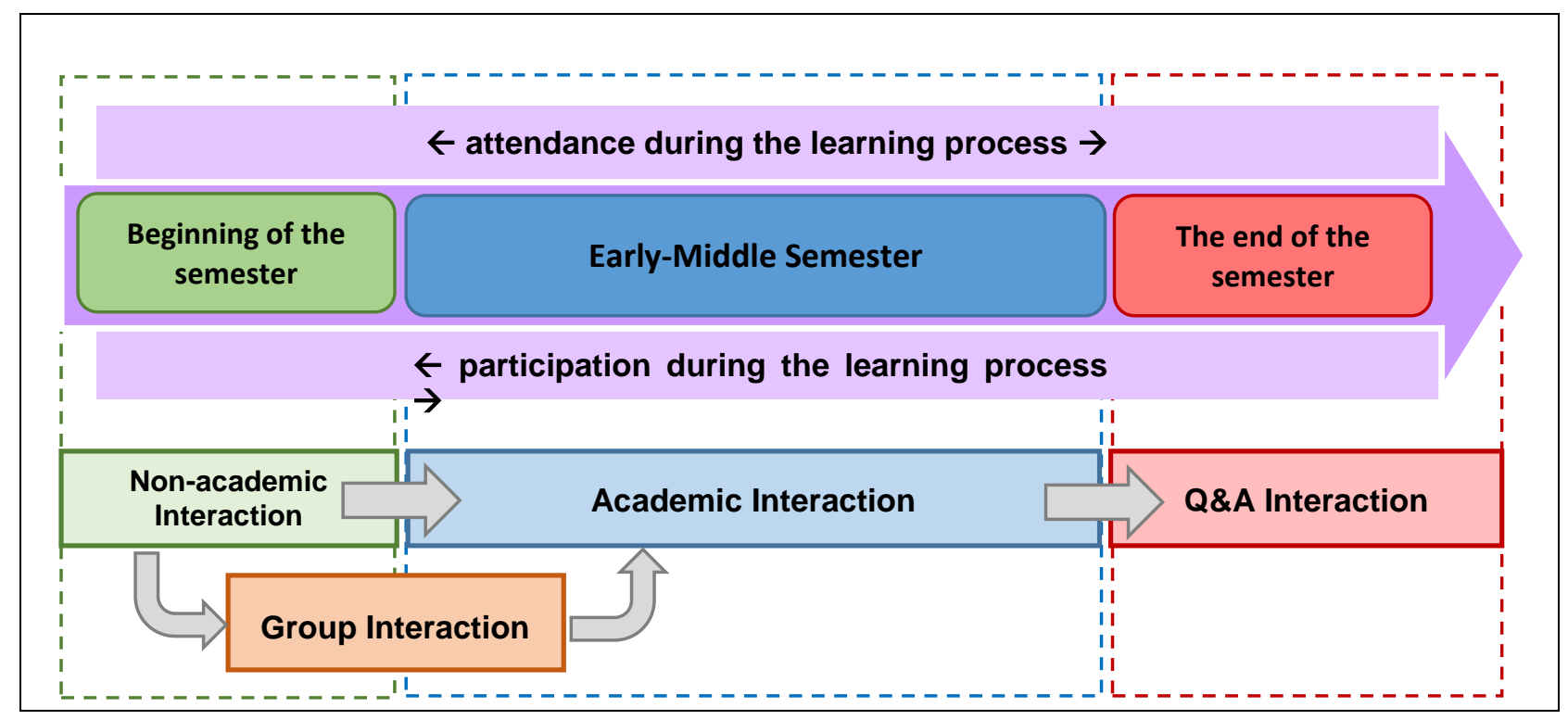

Figure 4. Conceptual Framework.

For maximum participation, researchers had established gradual time allocation for the use of each forum, as the gradual arrangement of interaction could encourage respondents to follow the activities as well as maintaining their interest to learn throughout the semester. Such activities provide rooms and opportunities for them to widen their learning process without the constraint of place and time through the use of webbased learning environment. Table 2 illustrates the duration for activities that was shown in the conceptual framework.

Table 2.

Duration for Activities.

\begin{tabular}{|c|c|c|c|}
\hline No & Time & Time Started & Duration \\
\hline 1. & Beginning of the semester & Week 1 @ 2 & $13-14$ weeks \\
\hline 2. & Early-Middle Semester & Week 2 @ 3 & $12-13$ weeks \\
\hline 3. & Late Semester & Week 10 to 14 & $1-2$ weeks \\
\hline
\end{tabular}

\section{RESEARCH FINDINGS}

diskusiMAYA platform used throughout the semester had provided collaborative tools through the use of forums. The use of forums was shaped by several categories namely Academic Forum, Non-Academic Forum, Group Forum and Q\&A Forum. The use of every forum serves to support new knowledge construction through formal, non-formal and indirect learning.

Construction of new knowledge through formal learning could be seen from participation in collaborative tools such as Academic Forum, Q\&A Forum and Group Forum. On the other hand, non-formal learning could be seen from participation in Non-academic Forum and Group Forum. Meanwhile, informal learning could be seen from attendance in all collaborative tools that are present in diskusiMAYA platform.

In the first research semester, through the Academic Forum activity report, researchers found that only 14 $(37.8 \%)$ respondents are active in giving comments (observe and post) while $32(86.5 \%)$ respondents prefer to only observe the comments (observe). However, there are $5(13.5 \%)$ respondents that did not join the activity at all. From the activity report of Q\&A Forum, researchers found that $35(94.6 \%)$ respondents are active in giving comments (observe and post). However, there are $2(5.4 \%)$ respondents that did not join the activity at all. Findings from the Non-academic Forum show that $23(62.2 \%)$ respondents had observed the comments (observe) and $14(37.8 \%)$ respondents did not participate in the activity. Meanwhile, findings from interaction in Group Forum shows 17 (45.9\%) active observer (observe) while from that 17, $13(35.1 \%)$ had given comments (observe and post). However, 20 (54.1\%) respondents did not participate in the activity at all. All the information is presented in Table 3. 
Table 3.

Forum Interaction throughout 14 Lecture Weeks for Respondents in First Research Semester (37 respondents)

\begin{tabular}{|c|c|c|c|c|}
\hline $\begin{array}{l}\text { Collaborativ } \\
\text { e Tool in dM }\end{array}$ & $\begin{array}{c}\text { Q\&A } \\
\text { FORUM } \\
\text { (Respondents } \\
\text { Involved) } \\
\end{array}$ & $\begin{array}{l}\text { ACADEMIC } \\
\text { FORUM } \\
\text { (Respondents } \\
\text { Involved) } \\
\end{array}$ & $\begin{array}{c}\text { NON-ACADEMIC } \\
\text { FORUM } \\
\text { (Respondents } \\
\text { Involved) }\end{array}$ & $\begin{array}{c}\text { GROUP } \\
\text { FORUM } \\
\text { (Respondents } \\
\text { Involved) } \\
\end{array}$ \\
\hline $\begin{array}{l}\text { Observing } \\
\text { Activity }\end{array}$ & $\begin{array}{c}36 \\
(97.3 \%)\end{array}$ & $\begin{array}{c}32 \\
(86.5 \%)\end{array}$ & $\begin{array}{c}23 \\
(62.2 \%)\end{array}$ & $\begin{array}{c}17 \\
(45.9 \%)\end{array}$ \\
\hline $\begin{array}{l}\text { Participating } \\
\text { Activity }\end{array}$ & $\begin{array}{c}35 \\
(94.6 \%)\end{array}$ & $\begin{array}{c}14 \\
(37.8 \%)\end{array}$ & $\begin{array}{c}8 \\
(21.6 \%)\end{array}$ & $\begin{array}{c}13 \\
(35.1 \%)\end{array}$ \\
\hline
\end{tabular}

For the second research semester as presented in Table 4, findings from Academic Forum shows that all respondents have participated (observe and post) in the forum activity. In the Q\&A Forum, all respondents have observed (observe) activity in the forum while only $5(45.5 \%)$ had given their comments (observe and post). Research finding from the interactions and forum posts had found that respondents with most activities (observe and post) in the academic-related forums (Academic Forum and Q\&A Forum) are those who perform well in the multimedia development course assessment that he/she attended. For interaction in the Non-academic Forum, almost all respondents are involved with at least observing (observe) activity in the forum except for only one $(9.1 \%)$ respondent who was not involved in the activity. For interaction in Group Forum, $8(72.7 \%)$ respondents were actively involved in giving response (observe and post). From the total number of 11 respondents, 10 had entered the forum only to observe (observe).

Table 4.

Forum Interaction throughout 14 Lecture Weeks for Respondents in Second Research Semester (11 respondents)

\begin{tabular}{|c|c|c|c|c|}
\hline $\begin{array}{c}\text { Collaborativ } \\
\text { e Tool in dM }\end{array}$ & $\begin{array}{c}\text { Q\&A } \\
\text { FORUM } \\
\text { (Respondents } \\
\text { Involved) }\end{array}$ & $\begin{array}{c}\text { ACADEMIC } \\
\text { FORUM } \\
\text { (Respondents } \\
\text { Involved) }\end{array}$ & $\begin{array}{c}\text { NON-ACADEMIC } \\
\text { FORUM } \\
\text { (Respondents } \\
\text { Involved) }\end{array}$ & $\begin{array}{c}\text { GROUP } \\
\text { FORUM } \\
\text { (Respondents } \\
\text { (nvolved) }\end{array}$ \\
\hline $\begin{array}{c}\text { Observing } \\
\text { Activity }\end{array}$ & $\begin{array}{c}11 \\
(100 \%)\end{array}$ & $\begin{array}{c}11 \\
(100 \%)\end{array}$ & $\begin{array}{c}11 \\
(100 \%)\end{array}$ & $\begin{array}{c}10 \\
(90.9 \%)\end{array}$ \\
\hline $\begin{array}{c}\text { Participating } \\
\text { Activity }\end{array}$ & 5 & 11 & 10 & 8 \\
$(45.5 \%)$ & $(100 \%)$ & $(90.9 \%)$ & $(72.7 \%)$ \\
\hline
\end{tabular}

From this research, relationship between the presence of respondent types on the use of forum was also considered by observing the types of respondent present throughout the research. By using diskusiMAYA questionnaire on 84 respondents, researchers identified the existence of 'Witnesses Learners', 'Social Learners' and 'Active Learners'. From Table 5, significant positive correlation could be seen between 'presence of witnesses learners' and 'use of forum' with 0.224 at $\alpha=0.01$.

Table 5.

Correlation between the Presence of Witnesses Learners on the Use of Forum.

\begin{tabular}{|l|c|c|c|}
\hline \multicolumn{2}{|c|}{ Correlation } & $\begin{array}{c}\text { Presence of } \\
\text { Witnesses } \\
\text { Learners }\end{array}$ & Use of Forum \\
\hline $\begin{array}{l}\text { Presence of Witnesses } \\
\text { Learners }\end{array}$ & Pearson Correlation & 1 & .224 \\
\cline { 2 - 4 } & Sig. (2-tailed) & & .042 \\
\cline { 2 - 4 } & $\mathrm{N}$ & 84 & 84 \\
\hline \multirow{3}{*}{ Use of Forum } & Pearson Correlation & .224 & 1 \\
\cline { 2 - 4 } & Sig. (2-tailed) & .042 & 84 \\
\cline { 2 - 4 } & $\mathrm{N}$ & 84 & \\
\hline \multirow{2}{*}{ N. Significant correlation at 0.01 level (2-tailed). }
\end{tabular}

From Table 6, significant positive correlation could be seen between 'presence of social learners' and 'use of forum' with 0.331 at $\alpha=0.01$. 
Table 6.

Correlation between the Presence of Social Learners on the Use of Forum.

\begin{tabular}{|l|l|c|c|}
\hline \multicolumn{2}{|c|}{ Correlation } & $\begin{array}{c}\text { Presence of } \\
\text { Social } \\
\text { Learners }\end{array}$ & Use of Forum \\
\hline \multirow{3}{*}{$\begin{array}{l}\text { Presence of Social } \\
\text { Learners }\end{array}$} & Pearson Correlation & 1 & .331 \\
\cline { 2 - 4 } & Sig. (2-tailed) & & .002 \\
\cline { 2 - 4 } & $\mathrm{N}$ & 84 & 84 \\
\hline \multirow{3}{*}{ Use of Forum } & Pearson Correlation & .331 & 1 \\
\cline { 2 - 4 } & Sig. (2-tailed) & .002 & 84 \\
\cline { 2 - 4 } & $\mathrm{N}$ & 84 & \\
\hline
\end{tabular}

**. Significant correlation at 0.01 level (2-tailed).

From Table 7, significant positive correlation could be seen between 'presence of active learners' and 'use of forum' with 0.334 at $\alpha=0.01$.

Table 7

Correlation between the Presence of Active Learners on the Use of Forum.

\begin{tabular}{|l|c|c|c|}
\hline \multicolumn{2}{|c|}{ Correlation } & $\begin{array}{c}\text { Presence of } \\
\text { Active } \\
\text { Learners }\end{array}$ & Use of Forum \\
\hline \multirow{2}{*}{$\begin{array}{l}\text { Presence of Active } \\
\text { Learners }\end{array}$} & Pearson Correlation & 1 & .334 \\
\cline { 2 - 4 } & Sig. (2-tailed) & & .001 \\
\cline { 2 - 4 } & $\mathrm{N}$ & 84 & 84 \\
\hline \multirow{3}{*}{ Use of Forum } & Pearson Correlation & .334 & 1 \\
\cline { 2 - 4 } & Sig. (2-tailed) & .001 & 84 \\
\cline { 2 - 4 } & $\mathrm{N}$ & 84 & \\
\hline
\end{tabular}

${ }^{* *}$. Significant correlation at 0.01 level (2-tailed).

\section{DISCUSSION}

This research had confirmed the existence of 4 types of respondents throughout the e-learning process in the semester, namely:

i) Participants that did not participate (missing in action learners),

ii) Participants that observe (witnesses learners),

iii) Social participants (social learners); and

iv) Active participants (active learners).

From Pearson correlation analysis, relationship between the presence of these groups on forum usage were also obtained, in which all groups have moderately strong and positive relationship with the presence of Witnesses' Learners group and use of forum $(r=0.224$ at the level $\alpha=0.01)$ while presence of Social Learners group and use of forum $(r=0.331$ at $\alpha=0.01)$ and presence of Active Learners and use of forum $(r=0.331$ at the level $\alpha=0.01)$. From those three correlations, it was found that presence of 'active learners' respondents have the significant positive correlation higher than 'witnesses learners' and 'social learners'. This gives important information on direct relationship between active respondents with the use of forum in diskusiMAYA platform. Next, significant positive correlation shows that the presence of 'witnesses' learners' is higher compared to 'social learners'. It shows that forums are used more by respondents who observe information compared to respondents who underwent social activities.

This shows that community support is really needed in an adult e-learning as stated by O'Neil (2006) that community roles are needed even though it will change with time. All collaborative learning activities through asynchronous communication interaction could be shown by the use of forum function which was shaped by this respondent group. Academic result obtained from the multimedia development course had proven that most active respondent in diskusiMAYA platform with higher point generated through The Most Active User function will achieve excellent result. Discussions for ongoing forum in online learning can describe that interactivity is a feature of the most important factors that have an impact on learning.

Observation was done on each forum in diskusiMAYA platform in which the findings had shown that every course in adult e-learning will consist of the following respondent groups: 
i) Quadrant 1 (participants that did not join): Respondents that did not participate at all in diskusiMAYA platform;

ii) Quadrant 2 (participants that observe): Respondents that like to observe on-going discussion;

iii) Quadrant 3 (social participants): Respondents that participate in social discussion; and

iv) Quadrant 4 (active participants): Respondents that actively participate in any discussion.

These respondents group could be associated with interaction with courses and their interpersonal characteristics to support their learning. From Figure 5, researchers categorized quadrant 1 and quadrant 2 as respondent group with tendency to learn individually. On the other hand, quadrant 3 and quadrant 4 is categorized as respondent group with tendency to learn collaboratively.

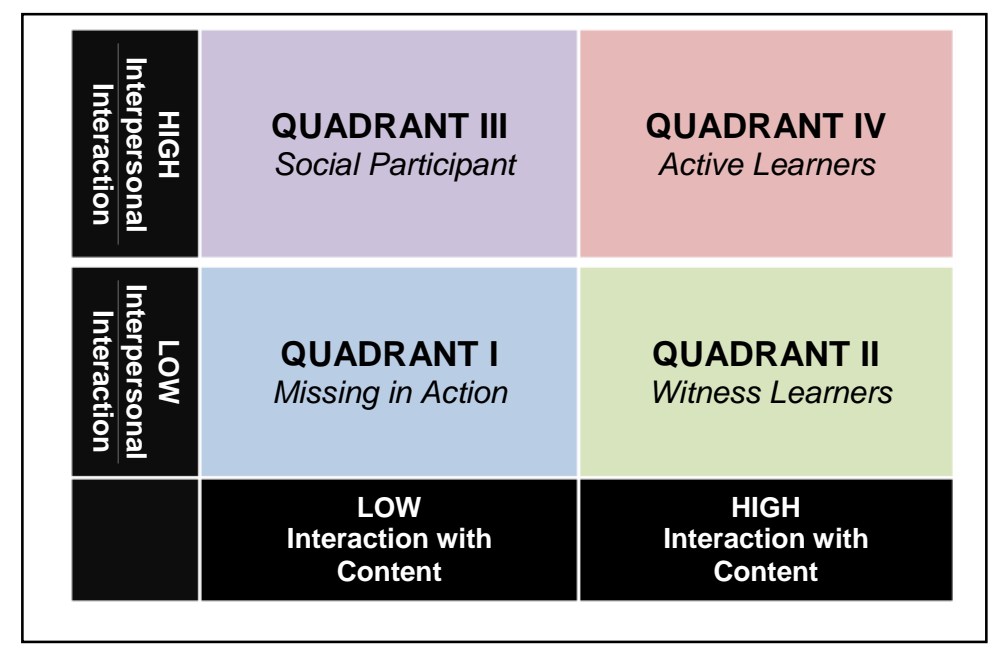

Figure 5. Categorization of Participant Interaction in e-learning.

From this figure, researchers found that at the second stage, relationship was found to exist between individual learning and collaborative learning. This shows that of an adult learner had read the content of a forum, probability of joining the social discussion is high. Figure 6 shows second and third quadrant which is in second stage there are the transition between non-participating users to active user.

For respondents that are not active in diskusiMAYA platform, but achieve good course result, they stated that they will join a discussion if they had read it. From that relationship, it shows that adult learners are encouraged to use e-learning as an effective way of learning in their community with the presence of useful input.

From the second quadrant, if the adult learners have the experience either in form of e-learning knowledge or skills, he/she will be able to contribute to new knowledge when another respondent read about the new information. The probability for one to join a social discussion is high as he/she had known about the information that was read. High participation will give basic experience for the next learner to continue learning. Second quadrant and third quadrant, which are in second stage are categorized as transitional quadrant which is important in shaping user that did not participate (witnesses learners) to be transformed into active learners. 


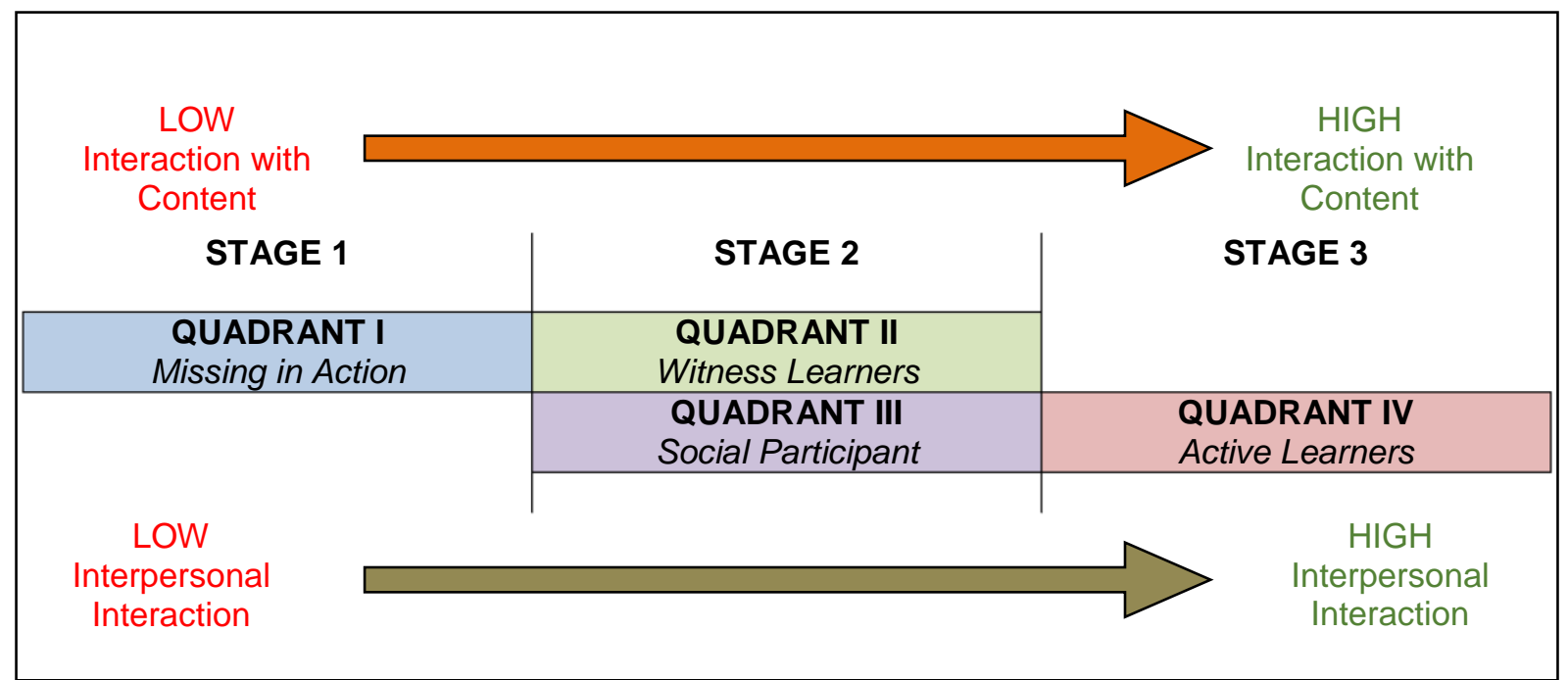

Figure 6. Relationship between Individual Preparation and Collaborative Learning in diskusiMAYA Platform.

With regard to user attendance in e-learning, no direct depiction could be given on the amount of interactions. This is because even though with small number of participant, interaction could still occur in which continuous learning could happen in diskusiMAYA platform. Types of interaction are not a requirement to ensure respondents participation in the activities. Research findings show that even though conditional activities were conducted on small number of participant, not all of them will contribute by participating in activities as determined. There will be those who will only observe and read without giving any additional comment.

Next, through Collaborative Taxonomy (Salmons, 2011), researchers found that first and second categories namely 'Reflection' and 'Dialogue' are the most generated interaction, while the most difficult interaction to be established in diskusiMAYA platform is interaction at stage 6 namely 'Synergized Collaboration'. 'Synergized Collaboration' requires the highest level of active participation from all competent group members using intermediary medium by regularly conducting critical discussion. Among the limitation that could be identified is due to different occupational background, imbalance of technical skills in meeting the course LO such as developing educational software and lack of reading, in which majority of the respondents are not active in attaching reading materials as reference in discussions.

\section{CONCLUSION}

The findings had achieved the research objectives which show that design of learning environment for groups of adult learners undergoing part-time course should have interaction elements involving academic interaction, non-academic interaction, group discussion and question and answer activities. It focuses on individual development and learning that occur within community through the use of e-learning. Indirectly, it could also unite all element of formal, no-formal and informal learning through the design of e-learning. Heutogogy design in e-learning environment could support respondents' learning activities along with interaction strategies for participation in learning activities and maintaining attendances in e-learning. Through diskusiMAYA platform, learning elements, learning opportunities, and experience sharing via gradual forum, learners were encouraged to continue their online learning.

\section{REFERENCE LIST}

Asia e University-AeU (2010). Dasar E-Pembelajaran Negara (DePAN) Untuk Institusi Pengajian Tinggi. Diperolehi pada November 11, 2010 dari http://psa.edu.my/v4/images/stories/UTM/Promosi/Dasar\%20e\%20Pendidikan\%20Negara\%5B1\%5D. pdf

Bailey, C. A. (2006). A Guide to Qualitative Field Research. Diperolehi pada Jun 26, 2010 dari http://www.sagepub.com/upm-data/13574_Bailey_Chapter_1.pdf 
Blaschke, L. M. (2012). Heutagogy and Lifelong Learning: A Review of Heutagogical Practice and SelfDetermined Learning. Diperolehi pada Feb 24, 2016 dari http://files.eric.ed.gov/fulltext/EJ979639.pdf

Burgess, J. (2008). Is A Blended Learning Approach Suitable For Mature, Part-Time Finance Students?. The Electronic Journal of e-Learning, 6 (2), 131-138. Diperolehi pada April 26, 2009, dari www.ejel.org

Choy, S. (2002). Findings from the Condition of Education 2002: Nontraditional Undergraduates. National Center for Education Statistics, Institute of Education Sciences, U.S. Department of Education. Washington, DC

Clark, R. C. \& Mayer, R.E. (2003). E-learning and the Science of Instruction. San Francisco: JosseyBass/Pfeiffer.

Corley, M. A. (2008). Adult Learning Theories. Diperolehi pada Ogos 3, 2009 dari http://www.calproonline.org/documents/AdultLearningTheoriesFinal.pdf

Cristophe, M. M., Thomas, J. A., \& Runnels, M. K. (2004). Raising The Bar: Encouraging High Level Thinking In Online Discussion Forums. Roeper Review, 26 (3), 166-171.

Davis, M. H. \& Harden, R.M. (2001). E is for Everything - Elearning? Medical Teacher, 23, 441-444.

Dib, C.Z. (1988). Cooperative Networks in Physics Education - Conference Proceedings 173. American Institute of Physics, New York. 300-315. Diperolehi pada Disember 17, 2009 dari http://www.technedib.com.br/downloads/6.pdf

Du, Z., Fu, X., Zhao, C., Liu, Q., and Liu, T. (2013). Interactive and Collaborative E-Learning Platform with Integrated Social Software and Learning Management System. Proceedings of the 2012 International Conference on Information Technology and Software Engineering. 212 (2). DOI: 10.1007/978-3-64234531-9_2.

Eberle, J. (2009). Heutagogy: What Your Mother Didn't Tell you About Pedagogy and the Conceptual Age. Proceedings of the European Conference on e-Learning, 181-188. Diperolehi pada September 9, 2012 dari http://academic-conferences.org/ecel/ecel2010/ecel09-proceedings.htm

Fidishun, D. (2000). Andragogy and Technology: Integrating Adult Learning Theory as We Teach With Technology. Diperolehi pada Disember 23, 2009 dari http://frank.mtsu.edu/ itconf/proceed00/fidishun.htm

Friend, M., \& Cook, L. (2003). Interactions: Collaboration Skills For School Professionals (3rd ed.). Boston: Allyn-Bacon.

Gulc, E. (2006). Using Blended Learning to Accommodate Different Learning Styles. Diperolehi pada 30, April 2009, dari http://escalate.ac.uk/downloads/2917.pdf

Hair, Jr., Anderson, R. R., Babin, B., Tatham, R. L. \& Black, W. C. (2006). Multivariate Data Analysis. (6th Ed). New Jersey: Prentice Hall.

Hase, S. \& Kenyon, C. (2001). Moving from Andragogy to Heutagogy: Implications for VET. Diperolehi pada Jun 6, 2010 dari http://epubs.scu.edu.au/gcm pubs/142

Huhns, M. \& M. Singh (2005). Service-Oriented Computing: Semantics, Processes, and Agents. England, John Wiley and Sons Ltd.Kurtus, R. (2004). Blended Learning. Diperolehi pada Januari 3, 2009 dari http://www.school-for-champions.com/elearning/blended.htm.

Janarthini, K. (2007). Faktor-faktor yang mempengaruhi Penggunaan e-Learning di Kalangan Pelajar Tahun Akhir Jabatan Multimedia (SPK, SPT dan SPP) Fakulti Pendidikan, Universiti Teknologi Malaysia. Tesis Sarjana Muda Sains dan Komputer serta Pendidikan (Matematik). Universiti Teknologi Malaysia, Skudai.

Knowles, M. S. (1975). Self-Directed Learning. Chicago. Follet.

Kurtus, R. (2004). Blended Learning. Diperolehi pada Januari 3, 2009 dari http://www.school-forchampions.com/elearning/blended.htm.

Lei, P \& Wu, Q (2007). Introduction to Structural Equation Modeling:Issues and Practical Considerations. Diperolehi pada Julai 31, 2011 dari http://ncme.org/linkservid/47EFEB5A-1320-5CAE6EC90BFDF09AA39E/showMeta/0/ 
Leonard L., \& Leonard P. (2003). The Continuing Trouble with Collaboration: Teachers Talk. Current Issues in Education, 6 (15). Diperolehi pada Feb 13, 2008 dari http://cie.asu.edu/volume6/number15/

Li, Y., Dong, M., \& Huang, R. (2011). Designing Collaborative E-Learning Environments based upon Semantic Wiki: From Design Models to Application Scenarios. Educational Technology \& Society, 14 (4), 49-63.

Lieb, S. (1991). Prinsiple of Adults Learning. Diperolehi pada Februari 13, 2008 dari http://honolulu.hawaii.edu/intranet/committees/FacDevCom/guidebk/teachtip/adults-2.htm

National Center for Education Statistics - NCES (2007). IPED Data Feedback Report 2007. Diperolehi pada Disember 18, 2008, dari http://www.csun.edu/senate/reports/IPEDS\%20Data\%20Feedback\%20Report\%202007.pdf

National Center for Education Statistics - NCES (2008a). The Condition of Education 2008. Diperolehi pada Disember 21, 2008, dari http://nces.ed.gov/pubsearch/pubsinfo.asp?pubid=2008031

O'Neil, T.D.(2006). How Distance Education Has Changed Teaching and the Role of the Instructor. Diperolehi pada November 4, 2009 dari http://www.gcasa.com/download/ONeil_Distance_Education.pdf

Orvis, K. A., Fisher, S.LI \& Wasserman, M.E. (2003). Am I E-nabled for E-learning?. Individual Differences and E-learning Reactions. 18th Anual Conference of The Society for Industrial and Organizational Psychology, Orlando, Florida. Diperolehi pada Mac 4, 2007, dari http://mason.gmu.edu/korvis1/elearning_SIOP2003.pdf

Salmons, J. E. (2011). An Overview of the Taxonomy of Collaboration. Diperolehi pada Februari 18, 2012, dari http://www.vision2lead.com/Taxonomy.pdf.

Shaw, F.S \& Giacquinta, J.B. (2000). A Survey of Graduate Students as End Users of Computer Technology: New Roles for Faculty. Information Technology, Learning, and Performance Journal, 33 (2), 44-55.

Smith, M. S. \& Broom, M. (2003). The Lanscape and Future of the Use of Technology in K-12 Education. Dalam: H. F. O'Neil, and R. S. Perez,. Technology Applications in Education: A Learning View. (3-32). New Jersey: Lawrence Erlbaum Associates.

Wang, M., \& Kang, M. (2006). Cybergogy for Engaging Learning: A Framework for Creating Learner Engagement Through Information and Communication Technology. In Hung, D., \& Khine, M. S. (eds). Engaged Learning with Emerging Technologies. Springer: Netherlands.

Woodall, D. (2010). Getting Started with e-Learning: Eight Questions to Consider. Diperolehi pada Januari 3, 2011 dari http://www.trackglobal.com/track/pdf/getting_started_with_elearning.pdf

Yan, Z., Hao, H., Hobbs, L. J., \& Wen, N. (2003). The Psychology of E-Learning: A Field Of Study. Diperolehi pada Jun 26, 2010 dari http://cecs5580.pbworks.com/f/psychology\%20of\%20elearning\%20field\%20of\%20study.pdf

Zaidatun Tasir, Norah Md Noor, Jamalludin Harun, \& Nurul Syazwani Ismail (2008). A Survey on Online Teaching Preference among Preservice Teachers in Malaysia: Andragogy vs Pedagogy. Diperolehi pada Februari 12, 2010 dari http://www.ascilite.org.au/conferences/melbourne08/procs/tasir.pdf 